\title{
LANDSCAPE VULNERABILITY ASSESSMENT USING REMOTE SENSING AND GIS TOOLS IN THE INDIAN PART OF KAILASH SACRED LANDSCAPE
}

\author{
Ajaz Hussain ${ }^{1, *}$, Gajendra Singh ${ }^{2}$, and Gopal S. Rawat ${ }^{1}$ \\ ${ }^{1}$ Wildlife Institute of India, Dehradun, India - (A.Hussain, G.S. Rawat)@wii.gov.in \\ ${ }^{2}$ Uttarakhand Space Application Centre, Dehradun, India - gajendrawat@yahoo.com
}

Commission V, SS: Disaster Monitoring, Damage Assessment and Risk Reduction

Key words: KSL, AHP, Vulnerability, Fire, Flood, Landslide

\begin{abstract}
The Indian part of Kailash Sacred Landscape (KSL) is prone to flash floods, landslides and forest fires leading to various environmental and socio-economic problems. This study aims to identify areas vulnerable to these disasters by preparing hazard maps to curtail their impact on the overall landscape. The Indian part of KSL covering seven forest ranges in Pithoragarh district which is spread over an area of 7,212 $\mathrm{km}^{2}$. This paper integrated the Geographic Information System and Remote Sensing and the multi criteria analysis through AHP to determine the disaster vulnerable areas in the landscape. All the thematic layers and final maps are prepared in ArcGIS 10.2. A total of ten variables for a landslide, six variables for flood and seven variables (topographic, climatic, and anthropogenic) were used to carry out the pairwise comparison for relatively weighting the variables through AHP. Consistency ratio $(\mathrm{CR}=0.01)$ for landslide and forest fire and for flood $(\mathrm{CR}=0.06)$ which shows the matrix was consistent. We identified $174 \mathrm{~km}^{2}$ of the area which is highly fired prone to forest fire, $76 \mathrm{~km}^{2}$ of area vulnerable to landslide and $24 \mathrm{~km}^{2}$ of the area comes under hotspot of the flood. The sites vulnerable to key drivers identified and mapped through this study will form the basis for further conservation and development planning at landscape level by policy makers.
\end{abstract}

\section{Introduction}

Kailash Scared Landscape is known for its rich spiritual, religious, ecologically diverse and cultural ethos rooted in traditions, but it is also known for growing natural disaster incidence, and highly vulnerable-ecologically fragile, geologically unstable and tectonically and seismically active.Owing to varied topography, the landscape is vulnerable to landslides, forest fires, flash floods affecting ecosystem services. These disasters havebeen known to cause major losses to ecosystem, resources, property, and life in the region and thereby affecting its process of economic development (Kazakiset et al., 2015). Vulnerability assessment is a crucial input to comprehend the degree of loss that the built environment suffers because of the occurrence of a natural disaster (Bhat et al., 2013).

Forest fires in the Indian part of KSL have been a common phenomenon that hascontinued to increase more frequently in last few decades due to rising temperatures during March to May and less winter rainfall (Roy et al., 2013). Majority of fire incidences are reported in moderately dense and open forest patches in the landscape generally between 600 - $2500 \mathrm{~m}$ altitudes. Forest fire event may burn areas, influencing the species composition and ecosystem and promote the regional domination of chir pine at the expense of broadleaf oak forests. Winter season fire in such areas have positive effect on habitat for certain species, however uncontrolled fire during summer month especially in broad leaf forest can be detrimental. In the absence of traditional fire management practices in this landscape, more areas are coming under forest fires. Low Precipitation during the

\footnotetext{
${ }^{*}$ Corresponding author
}

summer season in the landscape reduces the moisture in forested areas down at ground level, allowing the fire to catch more rapidly and spread quickly over the forestland. Besides, anthropogenic intervention for collection and extraction of timber, improvement of growth of grass, hunting wild animals, encroaching forestland, burning of pine needles, and burning of litter are all responsible for forest fire in the landscape (Negi et al., 2016).

Fragility, unpredictability,and activeness of terrain further highlight the landscape vulnerability (Bhatt et al 2013). The landscape is located in the center of the Indian Himalaya and one of the most fragile landscapes of the Himalayan Mountain system. Hazards like debris flow, landslides, and rock-falls are very common phenomena in the north and northwestern part of the landscape. Heavy rain during monsoon further emphasizes the intensity and frequency of these events, resulted in large-scale destruction of lives and property due to landslides as well as floods. This study deals with the first step of disaster risk management, i.e. to define the hazard area in the specific region. The objective of the study is to produce vulnerability maps of the study area with the integration of field survey data, GIS and remote sensing, which can help decision makers and government in the development and to reduce life and property loss from these disasters.

\section{Study Area}

KSL-India forms the study area having a larger part of Pithoragarh District $\left(30.0815^{\circ} \mathrm{N}\right.$, and $\left.80.3659^{\circ} \mathrm{E}\right)$ and a small part of Bageshwar District of Uttarakhand having an area of $7212 \mathrm{~km}^{2}$, altitudinal gradient from $350 \mathrm{~m}$ to 7,000 $\mathrm{m}$. Present study was focused in 12 selected villages in 'Horizontal Transect' (ICIMOD. 2010, KSL India Feasibility Report 2010) selected for various studies in 
KSL-India (figure 1). Agriculture is the primary occupation in most of the area. The landscape predominates in diverse forests (broad leaved in lower altitudes to temperate forests in higher elevation areas while extensive alpine pastures in areas between $3000-3500 \mathrm{~m}$ asl). The landscape has experienced rapidity of environmental changes and the global natures of socio-economic forces those have not only influenced the whole landscape but most of the ecosystems and associated elements have been notably transformed (ICIMOD. 2010, KSL India Feasibility Report 2010, Robert J. Z. et al. 2014).

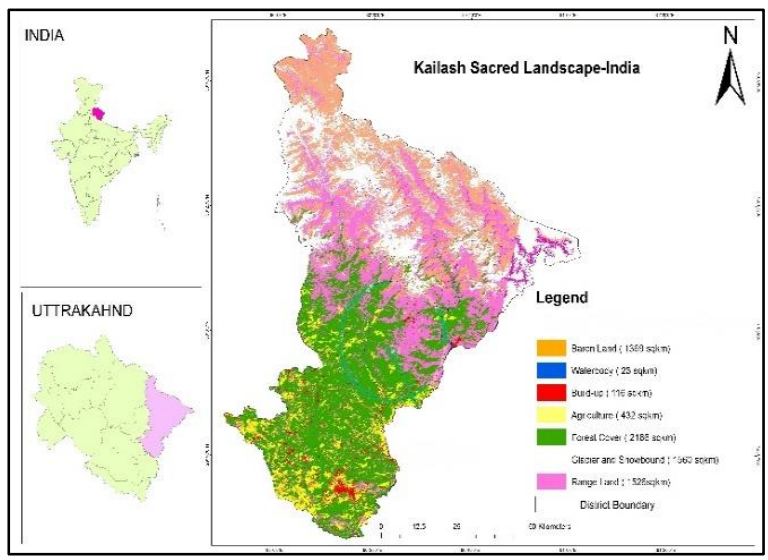

Figure 1: Map of the study area.

\section{Materials and Methods}

Vulnerability maps can be utilized in all steps of disaster management: prevention, mitigation, preparedness, operations, relief, recovery, and lesson learned. Landscape vulnerability analysis for KSL - India was performed in three steps: (i) Identification of natural and anthropogenic risks and hazards (ii) Assessment of vulnerable areas and (iii) mapping of hotspots and validation of results. Based on the literature review and extensive field observations we identified three major risks and hazards affecting ecosystem services in the KSL-India. These areLandslides, Forest Fires, and Floods. Landslides are among the most destructive geological processes that cause enormous damage to roads, bridges and housesand also lead to loss of human life in the landscape (UDR, 2014). Major routes to inner valleys and pilgrims trail to Holy Kailash are particularly vulnerable due to recurrent landslides. The forested tracts in KSL-India are more vulnerable to forest fires. Integratingthe remote sensing data, GIS and AHP are quite effective tools to generate vulnerability data (Rimba et al., 2017). The overall method of vulnerability assessment is given in figure 2. All the raster layers of parameter considered is prepared using ArcGIS 10.2. table 1 and figure 3 .

\section{Landslide Vulnerability Variables}

Various landslide, flood and forest fire predictor variables were used for susceptibility assessment, which are determined by literature review, viz., angle of slope (Bhatt et al., 2013; Kornejady et al., 2014; Pourghasemi et al., 2012; Wang et al., 2015), aspect (Pourghasemi et al., 2012;
Wang et al.,2015; Bhatt et al., 2013; Kornejady et al., 2014), distance from the drainage (Bhatt et al., 2013; Kornejady et al., 2015; Pourghasemi et al., 2012; Wang et.al. 2015), distance from the roads (Bhatt et al., 2013; Kornejady et al., 2015; Pourghasemi et al., 2012; Wang et.al. 2015; Moradi et al. 2012), distance from thrust and fault (Pourghasemi et al., 2012; Tseng et al., 2015; Wang et al.,2015), normalized difference vegetation index (NDVI), topographic wetness index (Pourghasemi et.al. 2012, Wang et.al. 2015), stream Power index (Pourghasemi et al., 2012; Wang et al., 2015) and plan curvature (Pourghasemi et al., 2012), all these variables are selected for landslide.

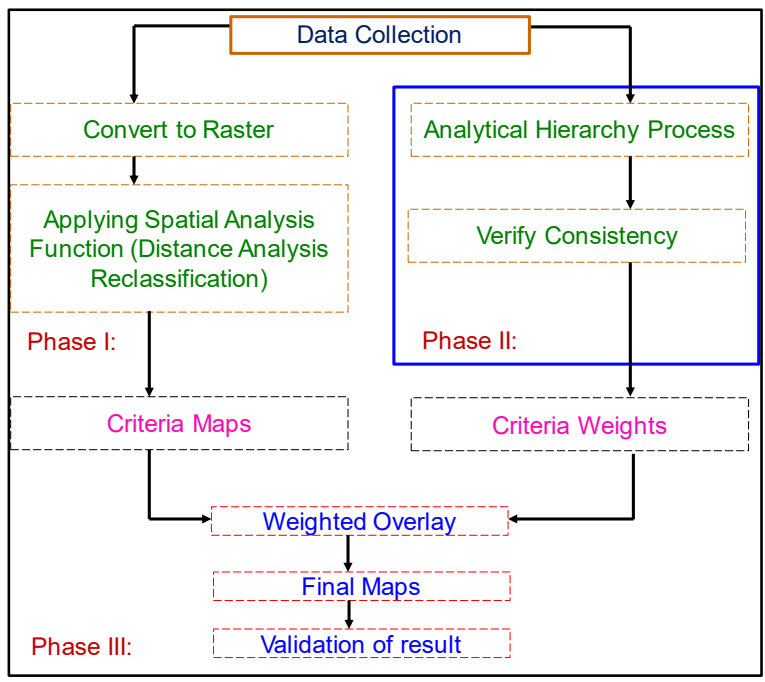

Fig 2: Flowchart for integrating spatial analysis with Analytical Hierarchy Process (AHP) (Satty in 1980).

We used six parameters for flood vulnerability analysis, namely rainfall (Rima et al.,2017; Ouma et al., 2014; Kazakis et al., 2015), flow accumulation (Kazakis et al., 2015), slope (Rimba et al.,2017; Ouma et al., 2014; Kazakis et al., 2015), soil type (Rimba et al.,2017), LULC (Rima et al.,2017; Ouma et al., 2014; Kazakis et al., 2015), and elevation (Rimba et al.,2017; Ouma et al., 2014; Kazakis et al., 2015). Seven parameters are considered for fire vulnerability analysis, namely rainfall, Temperature, NDVI, distance to road (Saklani, 2008; Amalina et al., 2016; Sahana et al. 2017), distance to stream (Amalina et al., 2016, Sahana et al. 2017), distance to settlement (Saklani, 2008; Amalina et al., 2016; Sahana et al. 2017), LULC (Saklani, 2008; Amalina et al., 2016; Chhetri et al., 2015; Sahana et al. 2017). Freely available geospatial imageries used for developing these layers were downloaded from different websites given in table 1 . ArcGIS 10.2was used to prepare various maps for the analysis in KSL-India. Topographic and climatic variables used for landslide vulnerability analysis were determined by literature review:

Flow accumulation: High values of accumulated flow indicate areas of concentrated flow and consequently higher flood hazard (Oman et al. 2014). The flow accumulation values vary in a range between 0-404 (Table 10 ), with the highest values occurring in the out flow of 
Maha Kali and Gori main tributaries. Lower values of this factor occur in streams of lower order.

The degree of slope and elevation: Degree of the slope is an important parameter for landslide hazard prediction (Bhatt et al. 2013. The slope class from $30^{\circ}-90^{\circ}$ covered most of the area in the landscape where the frequent landslide occurred. Slope angle map was prepared from DEM with using DEM surface tool. (Rimba et al.,2017; Ouma et al., 2014; Kazakis et al., 2015): - elevation and slope are the important factor for flood as well. Slope influences the amount of surface runoff and infiltration as Water flows from higher to lower elevations. Flat areas in low elevation may flood quicker than areas in higher elevation with a steeper slope (Kazkis et al., 2015). In the studied area, high-elevation appears in most of the area, where the slope is also steeper. Naturally, low slope and low elevation has been assigned the highest rating, as prone areas.

Distance to motor roads and settlement - Construction of roads using heavy machines and dynamite make undercutting of the slope, cracks on the surface and loss of soil, which makes the area more prone to landslide. Similarly, more fire incidences were observed closer to roads and human settlement due to accidents/negligence or deliberate actions of human beings. Hence, proximity to roads and settlements were an important predictor of landslides and forest fires.

Distance to thrust and faults: The rocks forming slopes in Himalaya have been reduced to successive deformation due to geological evolution of the terrain and present day tectonic activity along the edge of thrust and fault (Kazakis et al., 2015). The slope with multiple joint sets fail particularly during monsoon, when this region receives heavy rainfall. The slopes become saturated with water, destabilizing the slope beyond thestability limit. Rock fall, debris flow and complex landslides are various types of slope failure that occur.

Normalized difference vegetation index (NDVI): Changes in land cover conditions triggers change in the level of vulnerability of land. It is obvious that densely vegetated areas are departed from landslide events. The value is in range from -1 to $1,-1$ represents less and 1 represent dense vegetation cover.

Topographic Wetness Index (TWI): The topographic wetness index (TWI) has been used extensively to describe the effect of topography on the location and size of saturated source areas of runoff generation (Pourghasemi et al., 2012). TWI is calculated using Eq (2.1), proposed by moore et al. (1991), with the assumption that condition is steady and soil properties are uniform.

$$
\mathrm{TWI}=\ln (\mathrm{A} S / \tan \beta)
$$

where AS is the specific catchment's area $(\mathrm{m} 2 / \mathrm{m})$, and b is slope gradient (in degrees).

Stream Power Index : The stream power index (SPI) is a measure of the erosive power of water flow based on the assumption that discharge (q) is proportional to specific catchment area (As) (Eq. 2.2) (Pourghasemi et al., 2012; Moore et al.,1991).

$$
\mathrm{SPI}=\mathrm{A} S * \tan \beta
$$

where AS is the specific catchment's area $(\mathrm{m} 2 / \mathrm{m})$, and b the slope gradient in degrees. As the specific catchment's area and gradient increase, the amount of water contributed by upslope areas and the velocity of water flow increase; hence, the SPI and slope-erosion risk increase (Pourghasemi et al., 2012; Moore et al.,1991). Moore et al. (1993) stated that the SPI controls the potential erosive power of overland flow (Pourghasemi et al., 2012). Therefore, these processes can be considered as one of the components of landslide occurrence (Pourghasemi et al. 2012; Lee and Min 2001; Gokceoglu et al. 2005; Nefeslioglu et al. 2008; Yilmaz 2009; Akgun and Turk 2010).

Aspect: It is also considered as a landslide-conditioning factor and this factor has been considered in several studies. Some of the meteorological events such as the direction of the rainfall, amount of sunshine, the morphologic structure of the area affects the slope stability (Pourghasemi et al. 2012; Mohammadi, 2008).

lower order.

Rainfall: - Heavy Monsoon Rainfall, cloudburst in the landscape increases the intensity of flash flood along riverbanks, which makes rainfall one of the main contributing factors for flash flood in the landscape. Seasonal rainfall plays important role in forest fire. Less rainfall during winter season (December- January), causes low precipitation and humidity in the forest, which makes the forest prone to fire.

Landuse and: -Land use influences infiltration rate, the interrelationship between surface and groundwater as well as debris flow. Thus, the contribution of LULC in flood mapping is important.

LULC is one of the important parameters to know the extent of forest fire in the landscape, because forest fire mostly occurs in moderately dense and open forest. Such forest patches mostly share its boundary with human settlement and agriculture. The initial fire starts with surface fire and ground fire.

NDVI Factor: - Changes in land cover conditions triggers change in the level of vulnerability of land and forest fires. NDVI is a vegetation index developed by Rouse et al 1973. It shows the level of greenness of vegetation and the litter. The value is in range from -1 to $1,-1$ represent very sparse and 1 represent dense vegetation cover.

Plan curvature: The term plan curvature is the theoretically defined as the rate of change of slope gradient or aspect, usually in a particular direction. The slope affects the overall rate of movement downslope based on the shape of the slope (convex, concave or plain). The steep slope with convex and concave curves contribute more to landslides than the plain slopes and aspect defines the direction of flow of the rainwater. 
Table 1: Data sets used for in landscape vulnerability analysis in KSL-India.

\begin{tabular}{|l|l|l|}
\hline Data used & SOURCE & LINK \\
\hline $\begin{array}{l}\text { LULC (supervised classification } \\
\text { LANDSAT) }\end{array}$ & USGS (earth explorer) & https://earthexplorer.usgs.gov/ \\
\hline Slope, DEM, ASPECT & Generated from DEM & https://earthexplorer.usgs.gov/ \\
\hline Drainage, Roads & UKFD, WII & http://forest.uk.gov.in/contents/view/6/27/75-forest-fireinfo \\
\hline Climatic layers & Bioclim & http://www.worldclim.org/bioclim \\
\hline NDVI & MODIS (AppEEARS) & Ipdaacsvc.usgs.gov \\
\hline Soil & $\begin{array}{l}\text { HWSD (harmonized world soil } \\
\text { database) }\end{array}$ & $\begin{array}{l}\text { http://webarchive.iiasa.ac.at/Research/LUC/External-World-soil- } \\
\text { database/HTML/ }\end{array}$ \\
\hline Plan curvature & Generated from DEM & https://earthexplorer.usgs.gov/ \\
\hline Thrust & UKFD, WII & http://forest.uk.gov.in/contents/view/6/27/75-forest-fireinfo \\
\hline Fault & UKFD, WII & http://forest.uk.gov.in/contents/view/6/27/75-forest-fireinfo \\
\hline Fire points & $\begin{array}{l}\text { MODIS (FIRMS) } \\
\text { UKFD }\end{array}$ \\
\hline
\end{tabular}

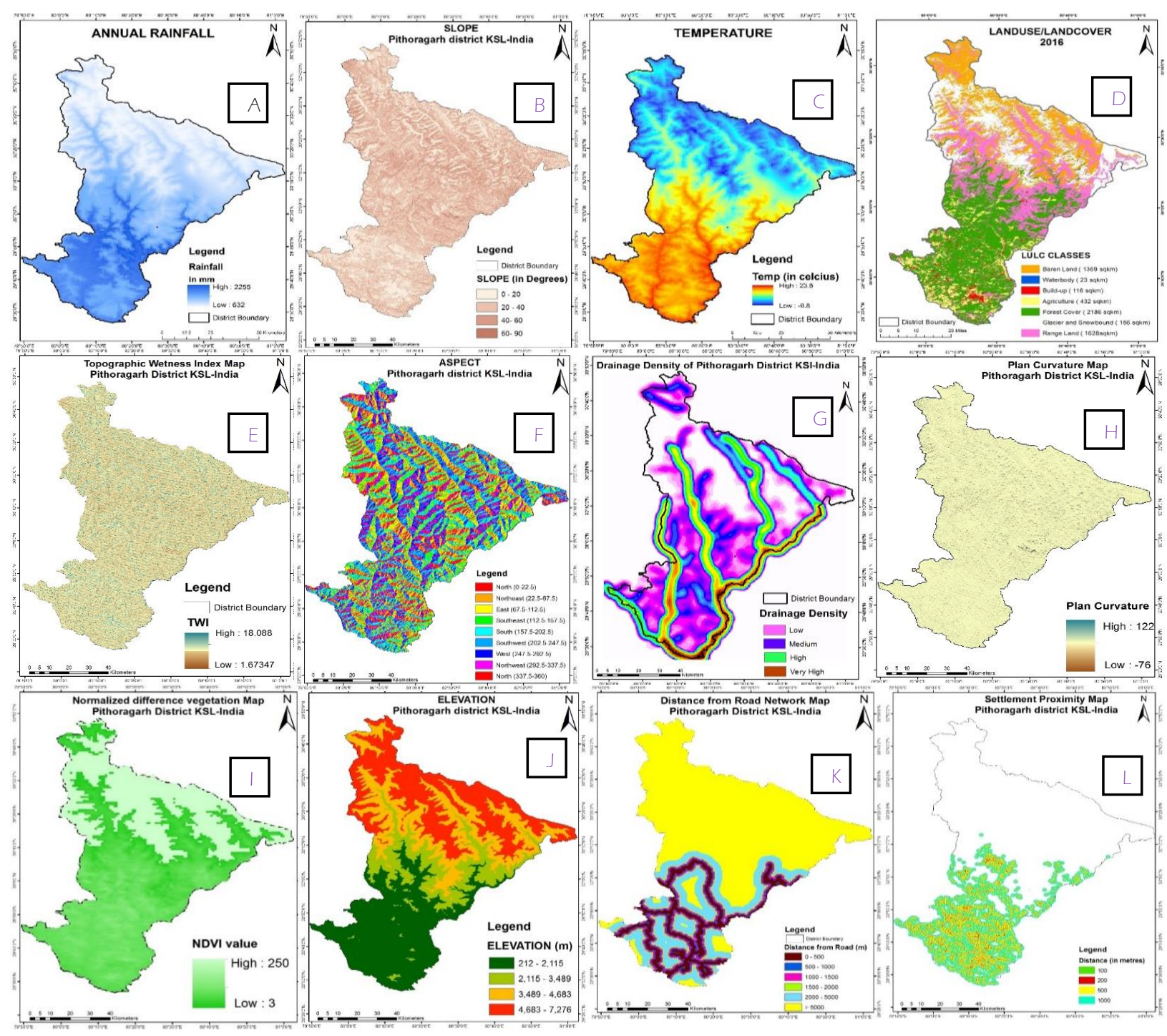

Fig 3: Parameters used for landscape vulnerability analysis through AHP are: (a) annual rain fall, (b) degree of slope, (c) temperature, (d) LULC, (e) Topographic Wetness Index, (f) aspect, (g) drainage density, (h) plan curvature, (I) NDVI, (j) elevation, (k) distance to road, (1) proximity to settlement. 


\section{Analytical Hierarchy Process (AHP)}

AHP is a decision-making technique utilized for solving complex problems, with many parameters of interrelated objectives or concerned criteria (Rimba et al., 2017). The level of the each of the contributing factor is not same; some parameters are dominant over others. Factors are compared with each other to determine the relative preference of each factor in accomplishing the overall goal. Rankingis assigned to each pair of the factors using the guidelines established in fundamental Satty 'sscale (Table 2). The relative importance has a range from 1 to 9 where 1 means an equal contribution of the pairwise parameter and 9 means a very important parameter. The number of parameters influences the matrix. The comparisons of parameters were generated from the expert judgment and literature review. The output of AHP has to be consistent for all the pairwise comparisons measured by Consistency Index (CI) and Consistency Ratio (CR). The CI follows Equation

\section{$\mathbf{C I}=\lambda \max -\mathbf{n} / \mathbf{n}-\mathbf{1}$}

Where $n$ is a numberof parameters and $\lambda$ max is calculated to normalize and find the relative weight of the matrix. The final calculation is consistency ratio; it is a ratio of the CI and random index (RI). The maximum threshold of CI is $\leq 0.1$ and $\mathrm{CR} \leq 10 \%$; the rational value is when the $\mathrm{CI}$ and $\mathrm{CR}$ have fulfilled the maximum threshold value. The consistency ratio (CR) followed Equation.

\section{$\mathbf{C R}=\mathbf{C I} / \mathbf{R I}$}

\section{Results}

The main use of AHP is the ranking and prioritizing of multi-criteria parameter. The weight is given to the design factors with the following procedure (Saaty T. L., 2008):

(1) Determine each factor percentage to distinguish the weight.
(2) Assign the least important factor from step 1 and assume the importance scale among the objective is linear. (3) The importance of factor should be ranked from 1 to 5 , where 1 represents the least important factor and 5 is the most important.

Ranking of each parameter was done by using pairwise comparison and the results are shown in table $(3,4,5)$ for landslide, flood and forest fire respectively. Thereafter, we normalized the matrix, shown in table $(6,7,8)$. The standardized raster layers were given weight by using the priority (Table 6), also called normalized principal eigenvector. Then, $\mathrm{CI}$ and $\mathrm{CR}$ are calculated to determine if comparisons are consistent. The $\mathrm{CR}$ ratio is designed in such a way that if $\mathrm{CR}<10 \%$, the ratio indicates a reasonable level of consistency in the pairwise comparison. Since the CR value for all the three pairwise comparisons is less than $10 \%$, the comparisons are consistent. $\mathrm{CR}$ value for forest fire and landslide is 0.01 and for flood it is 0.06 . The relative weight value is given in percentage. Ranking of parameters, their relative weight is listed in table $(9,10,11)$ for landslide, flood and forest fire respectively. The ranking of various parameters is based on literature review. The range of ranking was between 1 and 5 , where 5 signify highest influence and the lowest influence factor was 1 . The highest contributing factor for landslide was slope (32\%), followed by distance to thrust and fault (16\% each). Least contributing factor is distance to river $(3 \%)$. The highest contributing factor in case of flood is also slope $(42 \%)$, Followed by rainfall and flow accumulation contributing $20 \%$ and $16 \%$ respectively. Slope influence the flow direction. In case of forest fire, temperature is the most important governing factor, contributing $27 \%$, then come distance to road and settlement (14\% each). Once the weight is given, weighted overlay is performed in ArcGIS 10.2and maps for vulnerability are prepared

Table 3Matrix showing the couple comparison of the factors for landslide vulnerability; AHP

\begin{tabular}{|c|c|c|c|c|c|c|c|c|c|c|}
\hline Parameters & DT & $\mathrm{DF}$ & DR & $\mathrm{S}$ & $\mathrm{A}$ & $\mathrm{PC}$ & SPI & TWI & DD & NDVI \\
\hline Distance to thrust (DT) & 1 & 1 & 3 & $1 / 2$ & 5 & 3 & 4 & 4 & 5 & 2 \\
\hline Distance to fault (DF) & 1 & 1 & 3 & $1 / 2$ & 5 & 3 & 4 & 4 & 5 & 2 \\
\hline Distance to road (DR) & $1 / 3$ & $1 / 3$ & 1 & $1 / 6$ & 2 & 1 & 1.5 & 1.5 & 2 & 0.5 \\
\hline Slope (S) & 2 & 2 & 6 & 1 & 10 & 6 & 8 & 8 & 10 & 4 \\
\hline Aspect (A) & $1 / 5$ & $1 / 5$ & $1 / 2$ & $1 / 10$ & 1 & $1 / 2$ & $1 / 1.5$ & $1 / 1.5$ & 1 & $1 / 3$ \\
\hline Plan curvature $(\mathrm{PC})$ & $1 / 3$ & $1 / 3$ & 1 & $1 / 4$ & 3 & 1 & 2 & 2 & 3 & $1 / 2$ \\
\hline Stream power index (SPI) & $1 / 4$ & $1 / 4$ & $1 / 1.5$ & $1 / 8$ & 1.5 & $1 / 2$ & 1 & 1 & 1.5 & $1 / 2$ \\
\hline Topographic wetness index (TWI) & $1 / 4$ & $1 / 4$ & $1 / 1.5$ & $1 / 8$ & 1.5 & $1 / 2$ & 1 & 1 & 1.5 & $1 / 2$ \\
\hline Distance to drainage (DD) & $1 / 5$ & $1 / 5$ & $1 / 2$ & $1 / 10$ & 1 & $1 / 3$ & $1 / 1.5$ & $1 / 1.5$ & 1 & $1 / 3$ \\
\hline NDVI (ND) & $1 / 5$ & $1 / 5$ & 2 & $1 / 4$ & 3 & 2 & 2 & 2 & 3 & 1 \\
\hline
\end{tabular}


Table 4 Matrix showing the parameters of flood hazard: Analytical Hierarchy Process.

\begin{tabular}{|l|l|l|l|l|l|l|}
\hline Parameters & RF & FA & S & ST & LC & E \\
\hline Rainfall(RF) & 1 & 2 & $1 / 4$ & 3 & 3 & 3 \\
\hline $\begin{array}{l}\text { Flow } \\
\text { Accumulation } \\
\text { (FA) }\end{array}$ & $1 / 2$ & 1 & $1 / 4$ & 2 & 2 & 3 \\
\hline Slope (S) & 4 & 4 & 1 & 4 & 4 & 4 \\
\hline Soil type (ST) & $1 / 3$ & $1 / 2$ & $1 / 4$ & 1 & 1 & 2 \\
\hline LULC (LC) & $1 / 3$ & $1 / 2$ & $1 / 4$ & 1 & 1 & 2 \\
\hline Elevation (E) & $1 / 3$ & $1 / 2$ & $1 / 4$ & $1 / 2$ & $1 / 2$ & 1 \\
\hline
\end{tabular}

Table 5 Matrix showing the couple comparison of the factors for fire vulnerability

\begin{tabular}{|l|l|l|l|l|l|l|l|}
\hline Parameters & LC & ND & RF & T & DR & DD & DS \\
\hline LULC & 1 & 1 & $1 / 4$ & $1 / 4$ & $1 / 2$ & 3 & $1 / 2$ \\
\hline NDVI & 1 & 1 & $1 / 4$ & $1 / 4$ & $1 / 2$ & 3 & $1 / 2$ \\
\hline RF & 4 & 4 & 1 & 1 & 2 & 6 & 2 \\
\hline T & 4 & 4 & 1 & 1 & 2 & 6 & 2 \\
\hline DR & 2 & 2 & $1 / 2$ & $1 / 2$ & 1 & 4 & 1 \\
\hline DD & $1 / 3$ & $1 / 3$ & $1 / 6$ & $1 / 6$ & $1 / 4$ & 1 & $1 / 5$ \\
\hline DS & 2 & 2 & $1 / 2$ & $1 / 2$ & 1 & 4 & 1 \\
\hline
\end{tabular}

Table 6 Normalized Landslide Hazard Parameters: Analytical Hierarchy Process

\begin{tabular}{|l|l|l|l|l|l|l|l|l|l|l|l|l|}
\hline Parameters & DT & DF & DR & S & A & PC & SPI & TWI & DD & NDVI & PV & Percentage \\
\hline DT & 0.165 & 0.165 & 0.164 & 0.165 & 0.152 & 0.168 & 0.161 & 0.161 & 0.152 & 0.171 & 0.162 & $16 \%$ \\
\hline DF & 0.165 & 0.165 & 0.164 & 0.165 & 0.152 & 0.168 & 0.161 & 0.161 & 0.152 & 0.171 & 0.162 & $16 \%$ \\
\hline DR & 0.055 & 0.055 & 0.055 & 0.055 & 0.061 & 0.056 & 0.060 & 0.060 & 0.061 & 0.043 & 0.056 & $6 \%$ \\
\hline S & 0.330 & 0.330 & 0.327 & 0.330 & 0.303 & 0.336 & 0.322 & 0.322 & 0.303 & 0.343 & 0.325 & $32 \%$ \\
\hline A & 0.033 & 0.033 & 0.027 & 0.033 & 0.030 & 0.028 & 0.027 & 0.027 & 0.030 & 0.029 & 0.030 & $3 \%$ \\
\hline PC & 0.055 & 0.055 & 0.055 & 0.055 & 0.091 & 0.056 & 0.081 & 0.081 & 0.091 & 0.043 & 0.066 & $7 \%$ \\
\hline SPI & 0.041 & 0.041 & 0.036 & 0.041 & 0.045 & 0.028 & 0.040 & 0.040 & 0.045 & 0.043 & 0.040 & $4 \%$ \\
\hline TWI & 0.041 & 0.041 & 0.036 & 0.041 & 0.045 & 0.028 & 0.040 & 0.040 & 0.045 & 0.043 & 0.040 & $4 \%$ \\
\hline DD & 0.033 & 0.033 & 0.027 & 0.033 & 0.030 & 0.019 & 0.027 & 0.027 & 0.030 & 0.029 & 0.029 & $3 \%$ \\
\hline NDVI & 0.082 & 0.082 & 0.109 & 0.082 & 0.091 & 0.112 & 0.081 & 0.081 & 0.091 & 0.086 & 0.090 & $9 \%$ \\
\hline
\end{tabular}

Table 7: Normalized flood hazard parameters: Analytical Hierarchy Process

\begin{tabular}{|l|l|l|l|l|l|l|l|l|}
\hline Parameters & Rainfall & $\begin{array}{l}\text { Follow } \\
\text { Accumulation }\end{array}$ & Slope & Soil type & LULC & Elevation & PV & $\begin{array}{l}\text { Percentag } \\
\text { e }\end{array}$ \\
\hline RF & 0.154 & 0.240 & 0.111 & 0.261 & 0.261 & 0.200 & 0.205 & $20 \%$ \\
\hline FA & 0.077 & 0.120 & 0.111 & 0.174 & 0.174 & 0.200 & 0.143 & $14 \%$ \\
\hline S & 0.616 & 0.480 & 0.444 & 0.348 & 0.348 & 0.267 & 0.417 & $42 \%$ \\
\hline ST & 0.051 & 0.060 & 0.111 & 0.087 & 0.087 & 0.133 & 0.088 & $9 \%$ \\
\hline LC & 0.051 & 0.060 & 0.111 & 0.087 & 0.087 & 0.133 & 0.088 & $9 \%$ \\
\hline E & 0.051 & 0.040 & 0.111 & 0.043 & 0.043 & 0.067 & 0.059 & $6 \%$ \\
\hline
\end{tabular}

Table 8 Normalized forest fire parameters: Analytical Hierarchy Process

\begin{tabular}{|l|l|l|l|l|l|l|l|l|l|}
\hline Parameters & LULC & NDVI & Rainfall & Temperature & $\begin{array}{l}\text { Distance } \\
\text { from road }\end{array}$ & $\begin{array}{l}\text { Distance } \\
\text { from } \\
\text { drainage }\end{array}$ & $\begin{array}{l}\text { Distance } \\
\text { from } \\
\text { Settlement }\end{array}$ & $\begin{array}{l}\text { Priority } \\
\text { vector }\end{array}$ & $\begin{array}{l}\text { Percentage } \\
\text { LULC }\end{array}$ \\
\hline NDVI & 0.070 & 0.070 & 0.068 & 0.068 & 0.069 & 0.111 & 0.069 & 0.075 & $7 \%$ \\
\hline RF & 0.070 & 0.070 & 0.068 & 0.068 & 0.069 & 0.111 & 0.069 & 0.075 & $7 \%$ \\
\hline T & 0.279 & 0.279 & 0.273 & 0.273 & 0.276 & 0.222 & 0.276 & 0.268 & $27 \%$ \\
\hline DR & 0.279 & 0.279 & 0.273 & 0.273 & 0.276 & 0.222 & 0.276 & 0.268 & $27 \%$ \\
\hline DD & 0.140 & 0.140 & 0.136 & 0.136 & 0.138 & 0.148 & 0.138 & 0.139 & $14 \%$ \\
\hline DS & 0.023 & 0.023 & 0.045 & 0.045 & 0.034 & 0.037 & 0.034 & 0.035 & $3 \%$ \\
\hline
\end{tabular}

The vulnerability map of landslide is shown in figure 4. The vulnerability map of landslide depicts three vulnerability classes' viz., low, medium and high. The analysis reveals that nearly $73 \mathrm{~km}^{2}$ of the landscape are highly vulnerable to landslides. Of the various blocks, Munsyari has the highest landslide prone area $\left(37.61 \mathrm{~km}^{2}\right)$ followed by Askot $\left(15.44 \mathrm{~km}^{2}\right)$ and Dharchula $\left(12.8 \mathrm{~km}^{2}\right)$.
These areas fall in lower middle parts of Rāmgangā, Gori, and Kali valleys especially close to freshly constructed roads. Hazards like debris flow, landslides, and rock-falls are very common phenomena in the north and northwestern part of the landscape. Heavy rain during monsoon further emphasizes the intensity and frequency of these events, resulted in large-scale destruction of lives and property. 
Forest fire risk map is shown in Figure 5, classified under the category from very low to high. Area is calculated in ArcGIS and it reveals that a total $174 \mathrm{~km}^{2}$ of the study are highly prone to forest fires. These areas include moderately dense south facing slopes between elevations $500-2000 \mathrm{~m}$ ASL. Highest fire prone area falls under Didihat Range $\left(54.41 \mathrm{~km}^{2}\right)$ followed by Pithoragarh $\left(29.47 \mathrm{~km}^{2}\right)$ and Gangolihat $\left(23 \mathrm{~km}^{2}\right)$ and Munsyari $\left(23.34 \mathrm{~km}^{2}\right)$ ranges of KSL-India. The final geo-hazard map of flood is divided into four classes; low, medium, high and very highly vulnerable areas (Figure 6). For mitigation and management of flood prone areas, it has become important to identify the villages vulnerable to flash flood in the landscape. For that, we extract the hotspots area from the map and we found that 33 villages come under flood hotspots area covering $24 \mathrm{~km}^{2}$ along Maha kali, and Gori river in Dharchula, Bin, and Munshiyari block in the landscape which is shown in Figure 6.

In vulnerable sites, such as areas with very steep slopes, where natural disaster likely occurs, which can cause huge loss to life and property. In order to prevent the predicted outcome of these disasters, decision maker and planners should keep development at highly prone areas in check.

\section{Conclusion}

Disaster can occur anywhere anytime. We cannot stop the occurrence of disaster but we can minimize their impact. The main aim of the present study is to develop a methodology that identifies disaster prone areas for disaster mitigation and development. Areas vulnerable to flood, landslide and forest fire are identified in this study using integrated approaches of remote sensing, GIS, and spatial multi-criteria evaluation through the Analytical Hierarchy Process (AHP) approach.

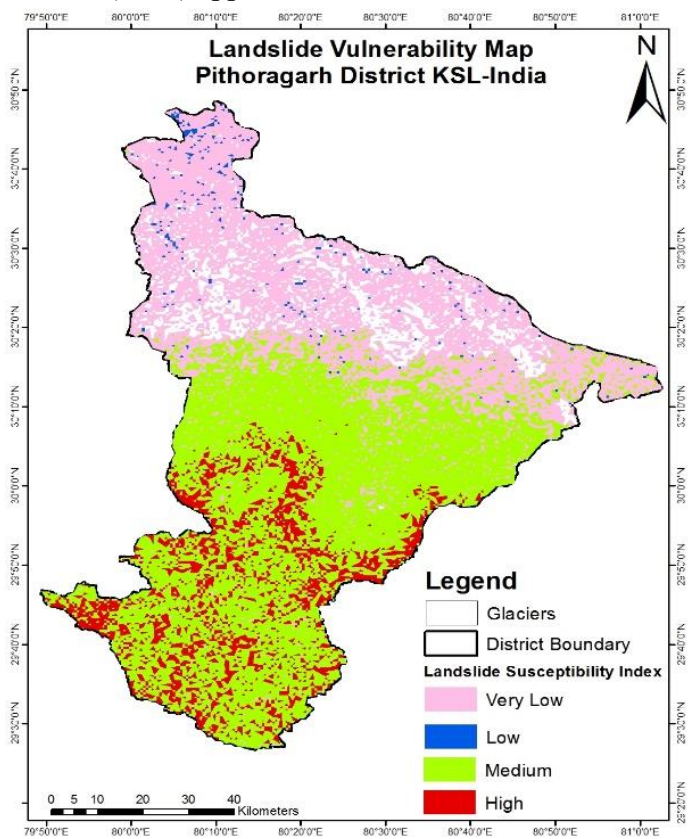

Fig 4: Landslide Prone Areas in Indian part of KSL

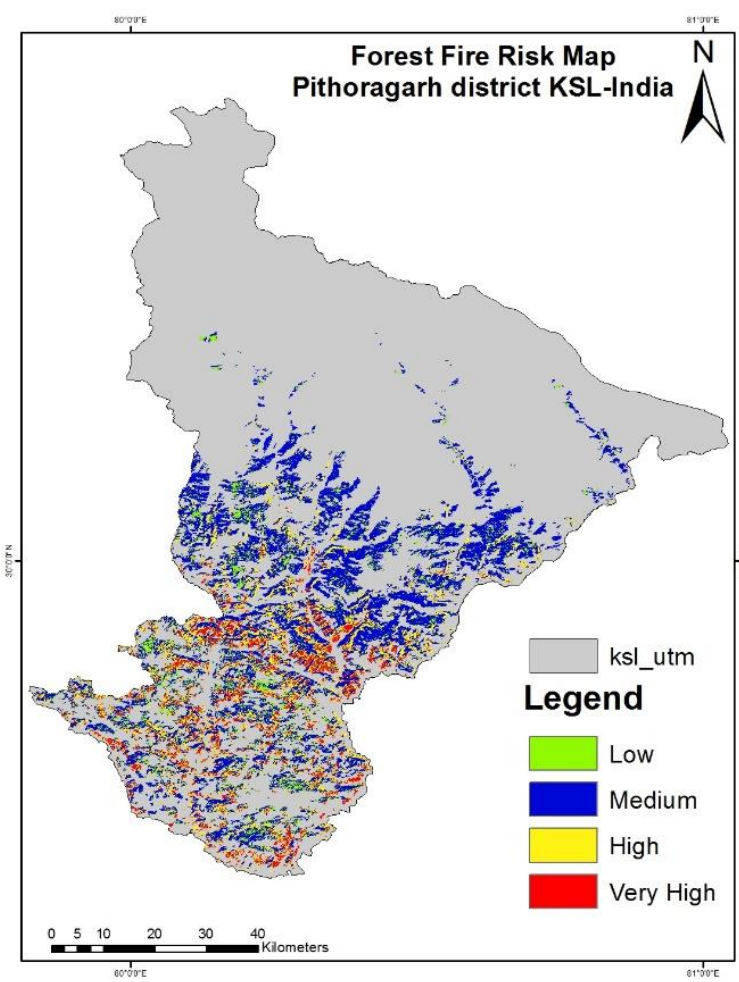

Fig 5: Forest Fire Prone Areas in Indian part of KSL

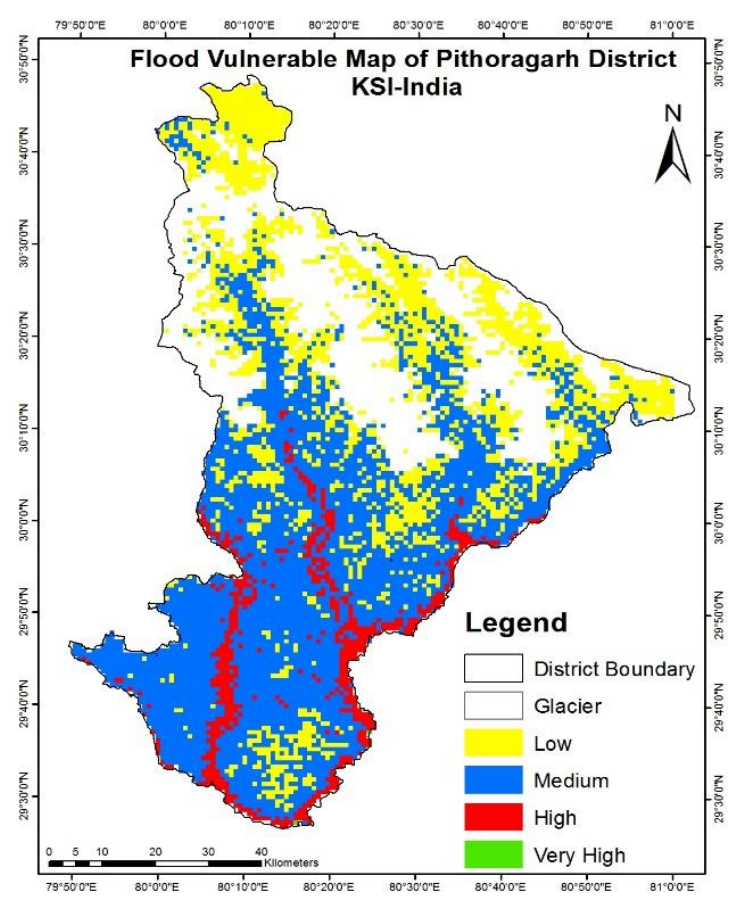

Fig 6: Flood vulnerability map of Indian part of KSL.

The AHP is the most frequently used multi-decision criteria based on the expert judgement and we can check the consistency of the rating, as well and pair-wisecomparison of parameters is quite appealing to the users. However, 
AHP too has a drawback, as it mostly relies on the input of experts, and to find experts is the difficult task.

Selection and inclusion of proper parameters are very important in generating a reliable and accurate vulnerability map. Ten causative factors were considered for landslide, namely, slope, aspect of the slope, distance to thrust and faults, distance to roads, distance to stream, NDVI, topographic wetness index and stream power index and plan curvature. From the study, it is concluded that slope is highest contributing factor because the driving force of mass increases with increasing slope. We used six parameters for flood vulnerability analysis, namely rainfall, flow accumulation, slope, soil type, LULC, and elevation, slope again is the most important factor because the slope influences the flow direction, runoff and soil infiltration. Forest fire parameters includedrainfall, Temperature, NDVI, distance to road, distance to stream, distance to settlement and LULC. Surface temperature, distance to road and settlement are the top three contributing factor. However, temperature providesgreater contribution to vulnerability of forest fire.

This study contributes an important approach for predicting the disaster-prone areas, which can help in effective mitigation and rural development. The same study can be carried out in other geographical areas with different topographical characteristics.

\section{Acknowledgements}

We would like to thank ICIMOD in providing funding for KSL-India. Great thanks to Wildlife Institute of India and USAC for supporting and giving facilities for vulnerability analysis at landscape level modelling. Heartfelt acknowledgements go to my friend Ms. Anchal Bhasin for her support in doing this analysis.

\section{References}

Akgun A, Turk N (2010) Landslide susceptibility mapping for Ayvalik (Western Turkey) 379 andits vicinity by multicriteria decision analysis. Env Earth Sci 61(3):595611

Amalina, P., Prasetyo, L. and Rushayati, S. (2016). Forest Fire Vulnerability Mapping in Way Kambas National Park.Procedia Environmental Sciences 33 (2016 ) 239 252

Ayalew, L., Yamagishi, H. and Ugawa, N. 2004. Landslide susceptibility mapping using GIS-based weighted linear combination, the case in Tsugawa area of Agano River, Niigata Prefecture, Japan. Landslides. 1: 73-81.

Bhatt B, Awasthi K, Heyojoo B, Silwal T, Kafle G. Using Geographic Information System and AnalyticalHierarchy Process in Landslide Hazard Zonation. Applied Ecology and Environmental Sciences, 2013, Vol. 1, No. 2, 14-22

Chhetri S, Kayastha P. Manifestation of an Analytic Hierarchy Process (AHP) Modelon Fire Potential Zonation Mapping in KathmanduMetropolitan City, NepalISPRS Int. J. Geo-Inf. 2015, 4, 400-417; doi:10.3390/ijgi4010400
Chuvieco E, Congalton RG. Application of remote sensing and geographic information system to forest fire hazard mapping. Remote Sens Environ 1989; 29: 147-159.

De Lange, H., Sala, S., Vighi, M.,and Faber, J. (2010). Ecological vulnerability in risk assessment - A review and perspectives. Science of The Total Environment, 408(18), pp.3871-3879.

Gokceoglu C, Sonmez H, Nefeslioglu HA, Duman TY, Can $\mathrm{T}$ (2005) The 17 March 2005 Kuzululandslide (Sivas, Turkey) and landslide-susceptibility map of its near vicinity. EngGeol81:65-83

ICIMOD (2010) Kailash sacred landscape conservation initiative: target area delineation report. ICIMOD, Kathmandu

Kazakis N, Kougias I, Patsialis T. Assessment of flood hazard areas at a regional scale using an index-based approach and Analytical Hierarchy Process: Application in Rhodope-Evros region, Greece. http://dx.doi.org/10.1016/j.scitotenv.2015.08.055 00489697/(C 2015 The Authors. Published by Elsevier

Kornejady, A., Heidari, K., Nakhavali, M. (2014). Assessment of landslide susceptibility, semi-quantitative risk,and management in the Ilam dam basin, Ilam, Iran. Environmental Resources Research Vol. 3, No. 1, 2015.

KSLCDI Feasibility Report (2010) Kailash Sacred Landscape Conservation Initiative, Feasibility Assessment Report. GBPHID Almora, ICIMOD, Katmandu. Unpublished Report

Lee S, Min K (2001) Statistical analysis of landslide susceptibility at Yongin, Korea. EnvironGeol 40:10951113

Mohammadi M (2008) Mass movement hazard analysis and presentation of suitable regionalmodel using GIS (Case Study: A part of Haraz Watershed), M.Sc. Thesis, TarbiatModarresUniversity International Campus, Iran, $\mathrm{p}$ 80

Moore ID, Grayson RB, Ladson AR (1991) Digital terrain modeling: a review of hydrological, geomorphological, and biological applications. Hydrol Process 5:3-30.

Moore ID, Gessler PE, Nielsen GA, Peterson GA (1993) Soil attribute prediction using terrainanalysis. Soil SciSoc Am J 57:443-452

Moradi M., Bazyar M., Mohammadi Z., -GIS Based Landslide Susceptibility Mapping by AHP Method, A Case Study, Dena City, Iran, Journal of Basic and Applied Scientific Research, 2(7), 9. 2012.

Nefeslioglu HA, Duman TY, Durmaz S (2008) Landslide susceptibility mapping for a part oftectonicKelkit Valley (Eastern Black Sea region of Turkey). Geomorphology 94:401-418 
Negi M, Kumar a. Assessment of increasing threat of forestfires in Uttarakhand, using remote sensing gandgis techniques. Volume 3, issue-6PP.457-468, ISSN:23945788

Nurdiana, A. and Risdiyanto, I. (2015). Indicator determination of forest and land fires vulnerability using Landsat-5 TM data (case study: Jambi Province). Procedia Environmental Sciences 24 ( 2015) $141-151$

Ouma, Yashon, Tateishi, Ryutaro, 2014. Urban flood vulnerability and risk mapping using integrated multi-parametric AHP and GIS: methodological overview and case study assessment. Water 6 (6), 15151545. http://dx.doi.org/10.3390/w6061515 (ISSN 20734441).

Pourghasemi, H.R., Pradhan, B., Gokceglu, C., andMoezzi, K. D. (2012). Landslide Susceptibility Mapping Using a Spatial Multi Criteria Evaluation ModelatHaraz Watershed, Iran. Springer-Verlag Berlin Heidelberg (2012)

Rimba, A., Setiawati, M., Sambah, A. and Miura, F. (2017). Physical Flood Vulnerability Mapping Applying Geospatial Techniques in Okazaki City, Aichi Prefecture, Japan. Urban Science, 1(1), p.7.

Robert J. Z., Antonio T., Marc J. M., Mingcheng W., Krishna P. O., Jianchu Xu. (2014) Projected climate change impacts on spatial distribution of bioclimatic zones and ecoregions within the Kailash Sacred Landscape of China, India, Nepal. Springer Science Business Media Dordrecht.

Romanescu, G., Hapciuc, O.E., Minea, I., Losub, M. 2016. Flood vulnerability assessment in the mountain-plateau transition zone: a case study of Marginea village (Romania). Journal of Flood Risk Management/ Volume 11 , issue $\mathrm{S} 1$

Roy P.S, Indian Institute of Remote Sensing (NRSA) Dehradun, Forest Fire and Degradation Assessment Using Satellite Remote Sensing And Geographic Information System

Sahana, M. \& Ganaie, T.A. (2017). GIS-based landscape vulnerability assessment to forest fire susceptibility of Rudraprayag district, Uttarakhand, India. Environ Earth Sci (2017) 76: 676. https://doi.org/10.1007/s12665-017-7008-8

Saklani, P. (2008). Forest Fire Risk Zonation, A case study PauriGarhwal, Uttarakhand, INDIA. Degree of Master. International Institute for Geo-information Science and Earth Observation.

Saaty T.L., The analytical hierarchy process, McGraw Hill, New York, 1980

Sati, V. (2014). Landscape vulnerability and rehabilitation issues: a study of hydropower projects in Garhwal region, Himalaya. Nat Hazards (2015) 75:2265-2278

Siddayao, G.P., Valdez, S.E. and Proceso, L.F. (2014). Analytic Hierarchy Process (AHP) in Spatial Modeling for Floodplain Risk Assessment. International Journal of
Machine Learning and Computing, Vol. 4, No. 5, October 2014

Tseng, C.M., Linand, C.W. and Hsieh, W.D. Landslide susceptibility analysis by means of event-based multitemporal landslide inventories (2015). Nat. Hazards Earth Syst. Sci. Discuss., 3, 1137-1173, 2015

Uttrakhand disaster report by National Institute of Disaster Management (Ministry of Home Affairs, Government of India)5-B, IIPA Campus, I.P. Estate, New Delhi - 110002, IndiaTel. +91-1123702432, 23705583, 23766146Website: www.nidm.gov.in

Wang, Q., Li, W., Chen, W. and Bai, H. (2015). GIS-based assessment of landslide susceptibility using certainty factor and index of entropy models for the Qianyang County of Baoji city, China. Journal of Earth System Science, 124(7), pp.1399-1415.

Wilson JP, Gallant JC (2000) Terrain analysis principles, and applications. Wiley, New YorkWood EF, Sivapalan M, Beven KJ (1990) Similarity and scale catchment storm response. RevGeophisics 28:1-18

Yilmaz I (2009) Landslide susceptibility mapping using frequency ratio, logistic regression,artificial neural networks and their comparison: a case study from kat landslides (Tokat-Turkey).CompGeosci 35(6):1125-1138

\section{APPENDIX}

Table 9Classes of the parameters and according weights for landslide vulnerability analysis.

\begin{tabular}{|c|c|c|c|}
\hline Parameters & Classes & Rating & Weight \\
\hline NDVI & $\begin{array}{l}-0.087- \\
0.001 \\
0.001- \\
0.117 \\
0.117- \\
0.303 \\
0.303-0.8 \\
0.8-0.9\end{array}$ & $\begin{array}{l}1 \\
2 \\
3 \\
4 \\
5\end{array}$ & $9 \%$ \\
\hline Thrust & $\begin{array}{l}0-2000 \\
2000- \\
5000 \\
5000- \\
8000 \\
8000- \\
45000 \\
45000- \\
67000 \\
\end{array}$ & $\begin{array}{l}5 \\
4 \\
3 \\
2 \\
1\end{array}$ & $16 \%$ \\
\hline Fault & $\begin{array}{l}0-4000 \\
4000- \\
12000 \\
12000- \\
18000 \\
18000- \\
50000 \\
50000- \\
82000\end{array}$ & $\begin{array}{l}5 \\
4 \\
3 \\
2 \\
1\end{array}$ & $16 \%$ \\
\hline $\begin{array}{l}\text { Plan } \\
\text { Curvature }\end{array}$ & $\begin{array}{l}-76.1--4 \\
-4--1\end{array}$ & $\begin{array}{l}5 \\
4 \\
\end{array}$ & $7 \%$ \\
\hline
\end{tabular}




\begin{tabular}{|c|c|c|c|}
\hline & $\begin{array}{l}-1-1 \\
1-10 \\
10-123.7\end{array}$ & $\begin{array}{l}1 \\
2 \\
3\end{array}$ & \\
\hline Slope & $\begin{array}{l}0-5 \\
5-15 \\
15-30 \\
30-45 \\
45-87\end{array}$ & $\begin{array}{l}1 \\
2 \\
3 \\
4 \\
5\end{array}$ & $32 \%$ \\
\hline TWI & $\begin{array}{l}-1-4 \\
4-8 \\
8-12 \\
12-18\end{array}$ & $\begin{array}{l}1 \\
3 \\
4 \\
5\end{array}$ & $4 \%$ \\
\hline SPI & $\begin{array}{l}-13.81--9 \\
-9-0 \\
0-5 \\
5-9.3 \\
\end{array}$ & $\begin{array}{l}1 \\
2 \\
4 \\
5\end{array}$ & $4 \%$ \\
\hline $\begin{array}{l}\text { Distance to } \\
\text { River }\end{array}$ & $\begin{array}{l}0-500 \\
500-1000 \\
1000- \\
2000 \\
2000- \\
5000 \\
5000- \\
15000 \\
\end{array}$ & $\begin{array}{l}5 \\
4 \\
3 \\
2 \\
1\end{array}$ & $3 \%$ \\
\hline $\begin{array}{l}\text { Distance to } \\
\text { Road }\end{array}$ & $\begin{array}{l}0-500 \\
500-1000 \\
1000- \\
1500 \\
1500- \\
2000 \\
2000- \\
5000 \\
5000- \\
78666\end{array}$ & $\begin{array}{l}5 \\
4 \\
3 \\
3 \\
2 \\
1\end{array}$ & $6 \%$ \\
\hline
\end{tabular}

Table 10Classes of the parameters and according weights for Flash Flood Vulnerability analysis.

\begin{tabular}{|l|l|l|l|}
\hline Parameters & Classes & Rating & Weight \\
\hline Rainfall & $632-1000$ & 1 & $20 \%$ \\
& $1000-1500$ & 2 & \\
& $1500-2000$ & 3 & \\
& $2000-2255$ & 5 & \\
\hline Flow & $0-90$ & 1 & $14 \%$ \\
Accumulation & $90-180$ & 2 & \\
& $270-360$ & 4 & \\
& $360-404$ & 5 & \\
\hline Slope & $0-20$ & 5 & $42 \%$ \\
& $20-40$ & 4 & \\
& $40-60$ & 3 & \\
& $60-90$ & 2 & \\
\hline Soil Type & Chestnut Soil & 2 & $9 \%$ \\
& Reddish & 5 & \\
& Brown Hill & 4 & \\
& Soil & 2 & \\
& Red Soil & & \\
& Lithosols & & $9 \%$ \\
& Barren Land & 1 & \\
& Settlement & 5 & \\
\hline LULC & Agriculture & 4 & \\
& Forest & 1 & \\
& & & \\
& &
\end{tabular}

\begin{tabular}{|l|l|l|l|}
\hline & Scrub & 1 & \\
& Glaciers & 1 & \\
& Range land & 1 & \\
\hline Elevation & $212-2,115$ & 5 & $6 \%$ \\
& $2,115-3,489$ & 4 & \\
& $3,489-4,683$ & 3 & \\
& $4,683-7,276$ & 1 & \\
\hline
\end{tabular}

Table 11 Classes of the parameters and according weights for Forest Fire Vulnerability analysis.

\begin{tabular}{|c|c|c|c|}
\hline Parameter & Classes & Rating & Weight \\
\hline Rainfall & $\begin{array}{l}632-1000 \\
1000-1500 \\
1500-2000 \\
2000-2255\end{array}$ & $\begin{array}{l}5 \\
3 \\
2 \\
1\end{array}$ & $27 \%$ \\
\hline Temperature & $\begin{array}{l}-9.8-5 \\
5-10 \\
10-15 \\
15-20 \\
20-23.5\end{array}$ & $\begin{array}{l}1 \\
2 \\
3 \\
4 \\
5\end{array}$ & $27 \%$ \\
\hline $\begin{array}{l}\text { Distance to } \\
\text { Road }\end{array}$ & $\begin{array}{l}0-100 \\
100-200 \\
200-500 \\
500-1000\end{array}$ & $\begin{array}{l}5 \\
4 \\
3 \\
2\end{array}$ & $14 \%$ \\
\hline $\begin{array}{l}\text { Distance to } \\
\text { Settlement }\end{array}$ & $\begin{array}{l}0-100 \\
100-200 \\
200-500 \\
500-1000\end{array}$ & $\begin{array}{l}5 \\
4 \\
3 \\
2\end{array}$ & $14 \%$ \\
\hline $\begin{array}{l}\text { Distance to } \\
\text { River }\end{array}$ & $\begin{array}{l}0-500 \\
500-1000 \\
1000-2000 \\
2000-5000 \\
5000-15000\end{array}$ & $\begin{array}{l}5 \\
4 \\
3 \\
2 \\
1\end{array}$ & $3 \%$ \\
\hline LULC & $\begin{array}{l}\text { Barren Land } \\
\text { Settlement } \\
\text { Agriculture } \\
\text { Forest } \\
\text { Scrub } \\
\text { Glaciers } \\
\text { Range land }\end{array}$ & $\begin{array}{l}1 \\
3 \\
3 \\
5 \\
5 \\
1 \\
3 \\
\end{array}$ & $7 \%$ \\
\hline NDVI & $\begin{array}{l}-0.087- \\
0.001 \\
0.001-0.117 \\
0.117-0.303 \\
0.303-0.8 \\
0.8-0.9\end{array}$ & $\begin{array}{l}1 \\
1 \\
4 \\
4 \\
5\end{array}$ & $7 \%$ \\
\hline
\end{tabular}

\section{Abbreviations}

\begin{tabular}{|l|l|}
\hline AHP & Analytical Hierarchy Process \\
\hline GIS & Geographic Information System \\
\hline GPS & Global Positioning System \\
\hline S & Slope \\
\hline LULC/ LC & Land use land cover \\
\hline E & Elevation \\
\hline RF & Rain Fall \\
\hline T & Temperature \\
\hline DR & Distance to road \\
\hline DS & Distance to settlement \\
\hline FA & Flow Accumulation \\
\hline ST & Soil type \\
\hline DRV & Distance to river \\
\hline
\end{tabular}


The International Archives of the Photogrammetry, Remote Sensing and Spatial Information Sciences, Volume XLII-5, 2018 ISPRS TC V Mid-term Symposium “Geospatial Technology - Pixel to People”, 20-23 November 2018, Dehradun, India

\begin{tabular}{|l|l|}
\hline NDVI & Normalize vegetation index \\
\hline DT & Distance to Thrust \\
\hline DF & Distance to Fault \\
\hline PC & Plan Curvature \\
\hline TWI & Topographic Wetness Index \\
\hline SPI & Stream Power Index \\
\hline
\end{tabular}

